University of Nebraska - Lincoln

DigitalCommons@University of Nebraska - Lincoln

Papers in the Earth and Atmospheric Sciences

Earth and Atmospheric Sciences, Department

\title{
Groundwater Recharge in Natural Dune Systems and Agricultural Ecosystems in the Thar Desert Region, Rajasthan, India
}

\author{
Bridget Scanlon \\ University of Texas at Austin, bridget.scanlon@beg.utexas.edu \\ Abhijit Mukherjee \\ Alberta Geological Survey \\ John B. Gates \\ University of Nebraska-Lincoln, jgates2@unl.edu \\ Robert C. Reedy \\ University of Texas at Austin, bob.reedy@beg.utexas.edu \\ Amarendra K. Sinha \\ University of Rajasthan
}

Follow this and additional works at: https://digitalcommons.unl.edu/geosciencefacpub

Part of the Earth Sciences Commons

Scanlon, Bridget; Mukherjee, Abhijit; Gates, John B.; Reedy, Robert C.; and Sinha, Amarendra K., "Groundwater Recharge in Natural Dune Systems and Agricultural Ecosystems in the Thar Desert Region, Rajasthan, India" (2010). Papers in the Earth and Atmospheric Sciences. 202.

https://digitalcommons.unl.edu/geosciencefacpub/202

This Article is brought to you for free and open access by the Earth and Atmospheric Sciences, Department of at DigitalCommons@University of Nebraska - Lincoln. It has been accepted for inclusion in Papers in the Earth and Atmospheric Sciences by an authorized administrator of DigitalCommons@University of Nebraska - Lincoln. 
Published in Hydrogeology Journal (2010) 18. Copyright 2010, Elsevier. Used by permission.

DOI: $10.1007 /$ s10040-009-0555-7.

\title{
Groundwater Recharge in Natural Dune Systems and Agricultural Ecosystems in the Thar Desert Region, Rajasthan, India
}

\author{
Bridget R. Scanlon, Abhijit Mukherjee, John B. Gates, Robert C. Reedy and Amarendra K. Sinha
}

\begin{abstract}
Water and nutrient availability for crop production are critical issues in (semi)arid regions. Unsaturated-zone $\mathrm{Cl}$ tracer data and nutrient $\left(\mathrm{NO}_{3}\right.$ and $\left.\mathrm{PO}_{4}\right)$ concentrations were used to quantify recharge rates using the $\mathrm{Cl}$ mass balance approach and nutrient availability in the Thar Desert, Rajasthan, India. Soil cores were collected in dune/ interdune settings in the arid Thar Desert (near Jaisalmer) and in rain-fed (nonirrigated) and irrigated cropland in the semiarid desert margin (near Jaipur). Recharge rates were also simulated using unsaturated zone modeling. Recharge rates in sparsely vegetated dune/interdune settings in the Jaisalmer study area are 2.7-5.6 mm/year (2-3\% of precipitation, $165 \mathrm{~mm}$ /year). In contrast, recharge rates in rain-fed agriculture in the Jaipur study area are 61-94 mm/year (10-16\% of precipitation, $600 \mathrm{~mm} /$ year). Minimum recharge rates under current freshwater irrigated sites are 50-120 mm/year (8-20\% of precipitation). Nitrate concentrations are low at most sites. Similarity in recharge rates based on $\mathrm{SO}_{4}$ with those based on $\mathrm{Cl}$ is attributed to a meteoric origin of $\mathrm{SO}_{4}$ and generally conservative chemical behavior in these sandy soils. Modeling results increased confidence in tracer-based recharge estimates. Recharge rates under rain-fed agriculture indicate that irrigation of $20-40 \%$ of cultivated land with $300 \mathrm{~mm} /$ year should be sustainable.
\end{abstract}

\section{Keywords}

India, Groundwater recharge/water budget, Nutrients, Land use, Sustainability.

Scanlon, Mukherjee, Reedy: Bureau of Economic Geology, Jackson School of Geosciences, University of Texas at Austin, Austin, TX, USA; e-mail: bridget.scanlon@beg.utexas.edu.

Mukherjee, present address: Alberta Geological Survey, Edmonton, AB, Canada.

Gates: Department of Earth and Atmospheric Sciences, University of Nebraska - Lincoln, Lincoln, NE, USA; e-mail: jgates2@unl.edu.

Sinha: Department of Geology, University of Rajasthan, Jaipur, Rajasthan, India.

\section{Introduction}

Water scarcity is a critical issue in (semi)arid regions, which cover about one-third of the Earth's total land surface and host $\sim 600$ million people (Postel 1997). Water use and food production are strongly linked because irrigated agriculture is the primary consumer of global freshwater resources, accounting for $\sim 90 \%$ of fresh groundwater consumption over the last century (Shiklomanov 2000; Scanlon et al. 2007a). India is particularly vulnerable to water and food scarcity because of its large population, 1.1 billion, with a projected increase of an additional 570 million in the next 50 years; temporal variability in precipitation ( $\sim 90 \%$ of precipitation in July, August, and September from the southwestern monsoon); and highest irrigated area by country globally -57 million hectares (Mha; UN-DESA-PD 2002; Kumar et al. 2005; Siebert et al. 2005).
Groundwater-fed irrigated area has expanded from 30\% ( $\sim 7$ Mha in 1960) to $\sim 50 \%$ ( 27 Mha in 1995; FAO 2008) and is likely to increase further as surface water supplies decrease after many of the glaciers have melted. The number of mechanized tube wells used for irrigation increased from 1 million in 1960 to 19 million in 2000 (Deb Roy and Shah 2003). Current groundwater production rates are mining groundwater resources, particularly in western India, where groundwater levels are declining and over half of the irrigation wells are out of commission as a result of insufficient supply (Deb Roy and Shah 2003). In addition to impacts of limited water availability on crop production, some studies suggest that nutrient availability may be a primary constraint on crop yield in (semi)arid regions (Rockstrom and deRouw 1997).

Groundwater availability problems are likely to be exacerbated in the future by climate change. Average 
annual temperature is estimated to increase by $3.3^{\circ} \mathrm{C}$ in India by the end of the twenty-first century (Christensen et al. 2007), and irrigation water demand is estimated to increase by $10 \%$ per ${ }^{\circ} \mathrm{C}$ (Fischer et al. 2002). Winter precipitation is projected to decrease and summer precipitation to become more intense with fewer rainy days, further intensifying the hydrologic cycle and potentially reducing groundwater recharge (Christensen et al. 2007). Gross per capita water availability in India is estimated to decline from $\sim 1,800 \mathrm{~m}^{3} /$ year in 2001 to $\sim 1,100 \mathrm{~m}^{3} /$ year in 2050 (Gupta and Deshpande 2004). These water scarcity problems will most likely translate to food scarcity. A critical issue that needs to be addressed is how much water and nutrients are available for sustainable crop production.

Regarding agriculture and water resources, there is currently considerable emphasis upon sustainability of natural resource utilization. The Brundtlandt Commission (1987) defined sustainable development as "...development that meets the needs of the present without compromising the ability of future generations to meet their own needs." Applying this concept to water resources suggests that water should only be consumed to the extent that it is renewable at human timescales. Some have criticized the use of recharge rates for assessing groundwater sustainability and argued that groundwater abstractions can be derived from increased recharge and decreased discharge, termed capture (Bredehoeft 2002; Devlin and Sophocleous 2005). However, in (semi)arid regions with generally deep water tables and very little surface water, pumpage is unlikely to capture surface flows. In these cases, recharge rates should, in the proper context, provide a good indication of the upper bound for sustainable groundwater abstraction rates. In addition to considering water quantity, sustainability should also address water quality issues, and development should try to minimize degradation of water resources.

Many studies have shown that subsurface flow through thick unsaturated zones can be approximated by pistontype flow (Cook and Herczeg 2000; Scanlon et al. 2007a). The concept of hydrostratigraphy can be applied to these flow systems to describe the resultant stratification or layering of pore water of different ages with depth. The subsurface distribution of environmental $\mathrm{Cl}$ tracer from bulk precipitation (precipitation and dry fallout) can be used to date the pore water and quantify past recharge rates (Allison and Hughes 1983; Scanlon et al. 2002). Chloride from bulk precipitation moves into the soil zone with infiltrating water. Drainage or percolation below the root zone is termed "potential recharge" and equated to eventual recharge at the water table. The age of unsaturated zone pore water is estimated by dividing the mass of $\mathrm{Cl}$ by the $\mathrm{Cl}$ input from bulk precipitation (wet and dry fallout). Chloride concentrations in soil water are inversely related to recharge rates: low $\mathrm{Cl}$ concentrations indicate high water recharge because $\mathrm{Cl}$ is flushed through the soil zone, whereas high $\mathrm{Cl}$ concentrations indicate low recharge because $\mathrm{Cl}$ is excluded when plants take up water and $\mathrm{Cl}$ builds up in the soil. Recharge is generally calculated using the chloride mass balance (CMB) approach (Allison and Hughes 1983). The hydrostratigraphic records trace past changes in recharge in response to variations in forcing from land-use change and climate variability (Scanlon et al. 2005, 2007a; Gates et al. 2008; Favreau et al. 2009). Unsaturated zone pore water $\mathrm{NO}_{3}$ concentrations provide information on whether there is natural $\mathrm{NO}_{3}$ in the profile from atmospheric deposition, as found in parts of the southwestern USA (Walvoord et al. 2003), from nitrogen fixation by native vegetation, as found in Senegal (Deans et al. 2005), or from mineralization and nitrification of soil organic nitrogen and over application and leaching of applied fertilizers in cropland areas (Scanlon et al. 2008). Large $\mathrm{NO}_{3}$ reservoirs in unsaturated media or in groundwater can be considered a resource for crop production, minimizing the need for fertilizer application (Deans et al. 2005). Unsaturated zone soil cores and associated soil water $\mathrm{Cl}, \mathrm{NO}_{3}$, and $\mathrm{PO}_{4}$ concentrations can be used to assess relationships between land use/land cover and climate, and subsurface water and nutrient cycles. These hydrostratigraphic records of water and nutrients are particularly valuable in remote (semi)arid regions where establishing and maintaining monitoring programs is extremely difficult.

In addition to use of the $\mathrm{CMB}$ approach to estimate recharge rates, numerical modeling is also widely used to estimate recharge rates in (semi)arid regions and to isolate controls such as climate forcing, vegetation, or soil type, on groundwater recharge. Fayer et al. (1996) used 1-D, unsaturated zone modeling to estimate recharge related to a variety of land use/land cover types in a semiarid region in northwest USA. Keese et al. (2005)used recharge modeling based solely on online data (precipitation, vegetation, and soils) to isolate controls on groundwater recharge and developed a map of recharge related to precipitation from 1-D simulations in different settings. Scanlon et al. (2003) simulated recharge over millennial time scales to compare with results from $\mathrm{Cl}$ tracer data in semiarid regions in the southwestern USA. The widespread availability of online data, including climatic forcing (Rodell et al. 2004), soil texture and related hydraulic databases, and vegetation data, greatly facilitates modeling analyses. Unsaturated zone modeling also provides a valuable tool to test the reliability of recharge estimates based on tracer data.

The objective of this study was to quantify recharge rates and nutrient reservoirs in the unsaturated zone for sustainable groundwater development and crop production in arid dune/interdune settings to the west in the Thar Desert and in semiarid cultivated settings along the margin of the desert to the east. Limited previous information on recharge in this region is based mostly on distribution of injected tritium in the unsaturated zone, which provides recharge estimates in natural grassland settings for the monsoon period after tracer injection (Rangarajan and Athavale 2000). The current study differs from previous studies in that it provides long-term (decadal) average recharge rates. The study areas should also provide information on controls on groundwater recharge because climate in the study areas ranges from arid to semiarid and 
land use ranges from natural, sparsely vegetated dunes to nonirrigated (rain-fed) and irrigated cropland. Information on subsurface water availability and nutrient levels in the cultivated region to the east will be valuable for assessing sustainability of crop production in this area.

\section{Background}

\section{Study area characteristics and history}

The Thar Desert, also known as the Great Indian Desert, is the seventh-largest desert in the world. It covers northwest India, mostly in the state of Rajasthan $\left(340,000 \mathrm{~km}^{2}\right.$ area) and southeast Pakistan. There is generally no integrated surface drainage system to the nearest ocean; surface water drains to varying-sized depressions or playas, which evaporate and often contain alkaline brine. Because of scarcity of surface water resources, inhabitants depend mostly on groundwater. Groundwater development is much more intensive in the eastern semiarid areas than in the western arid parts because of land use and population growth.

\section{Western study area}

The western study area is within a $\sim 50-\mathrm{km}$ radius of the city of Jaisalmer in the district of Jaisalmer, with an average elevation of 150-200 m above mean sea level (Figure 1). Geomorphology consists mostly of extensive ancient and modern dune fields and interdune plains (Figure $2 \mathrm{a}, \mathrm{b})$. The modern dunes (5-40 $\mathrm{m}$ high), which are mostly transverse (Barchan) type dunes, are oriented NE-SW and are composed of medium to fine sand. Interdune plains consist of coarse sand overlying weathered bedrock. The climate is arid to extremely arid (UNEP 1991). Mean annual precipitation (MAP) is $178 \pm 92$ (1 standard deviation, SD) mm (Fatehgarh, 1929-1967 omitting 1951-1953 because of minimal data) and $155 \pm 67 \mathrm{~mm}$ (Nachna, 19301966 omitting 1950-1953 and 1966) (Source: Global Historic Climatic Network, GHCN, Vose et al. 1998). Most precipitation $(77-78 \%)$ occurs during the summer monsoon in July and August (Figure 3). Average temperature in Jaisalmer ranges from $7.9^{\circ} \mathrm{C}$ (January) to $41.6^{\circ} \mathrm{C}$ (May) (SRSA 1999). Potential evapotranspiration (PET) (1,800 to $>2,000 \mathrm{~mm}$ /year; SRSA 1999) generally exceeds annual precipitation, even during the monsoon season. Groundwater exists mostly in Mesozoic to Tertiary sandstone and limestone aquifers (Sahai et al. 1993; SRSA 1999). Unsaturated zone thickness varies from 100 to $150 \mathrm{~m}$ in dune fields and generally $\leq 60 \mathrm{~m}$ in interdunes.

Because of scarcity of precipitation and groundwater, cultivation is limited to rain-fed agriculture in a few interdune plains. The crops, mostly pearl millet, barley, and fodder, depend on monsoonal rainfall and are generally grown once every 2-3 years, depending on precipitation. An irrigation canal ( $30 \mathrm{~m}$ wide) was constructed in the northwestern part of the study area (Indira Gandhi Canal Project) to supply water from tributaries of the Indus River to highly water scarce villages in the area (Figure 1). Plantations have been developed in certain regions along the canal to provide windbreaks and reduce sand migration into the canal (Figure 2c; Jain et al. 2007).

\section{Eastern study area}

The eastern study area is north and west of the city of Jaipur (capital of Rajasthan state), in the district of Jaipur
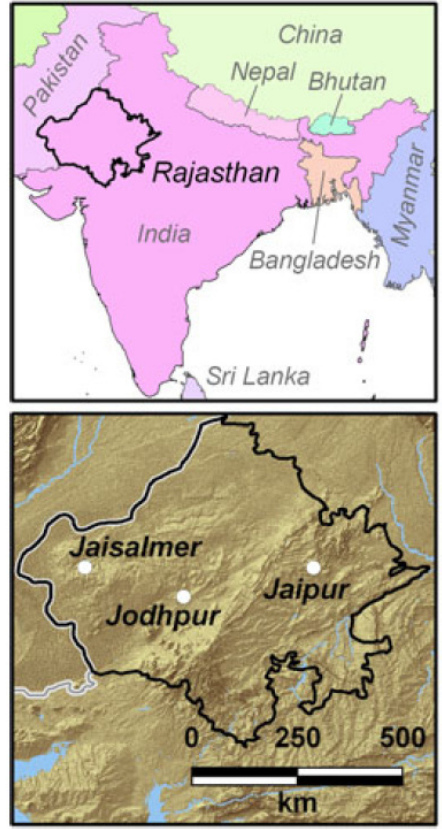
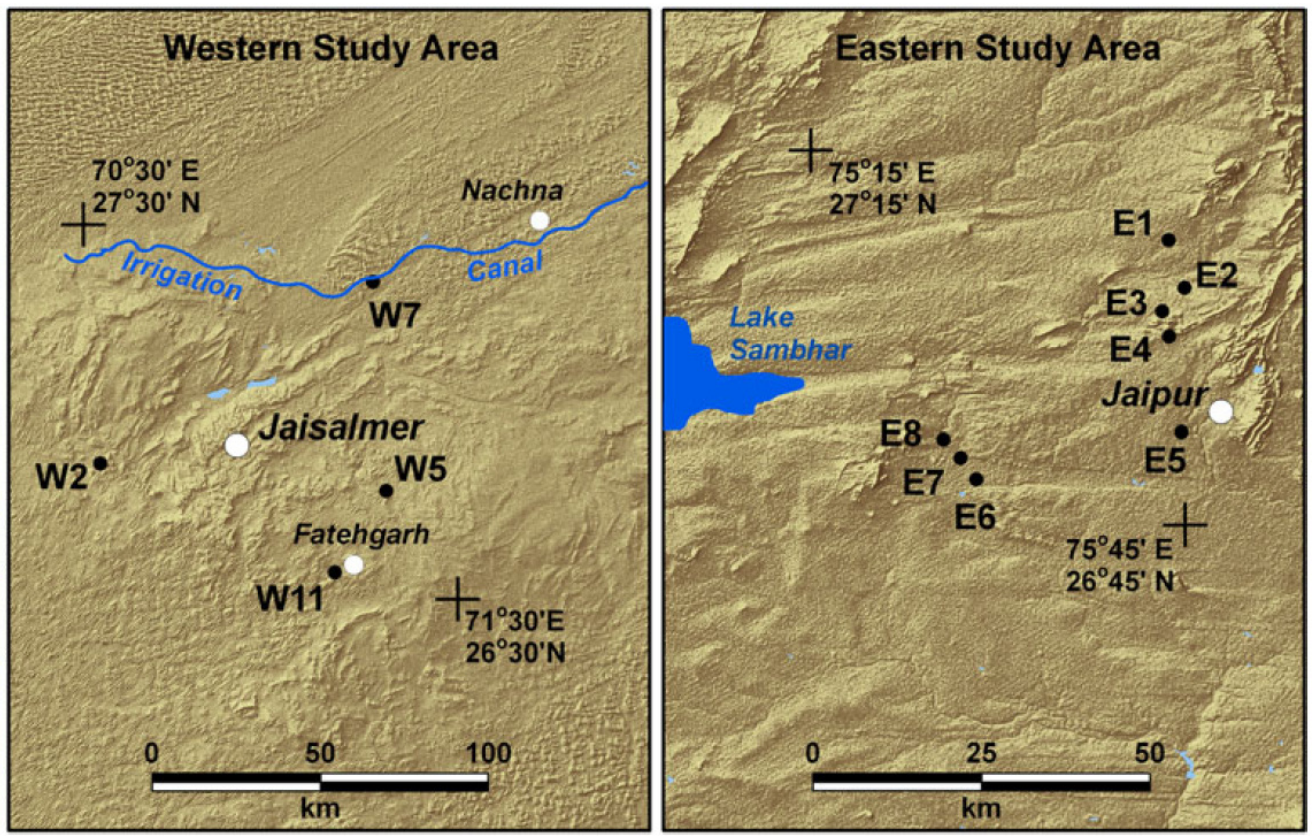

Figure 1. Shaded relief maps showing western (near Jaisalmer) and eastern (near Jaipur) study areas in Rajasthan, India. Towns/cities shown with white symbols, and borehole locations shown with black symbols. Borehole settings: W2 and W5, dune; W11, interdune; W7, interdune plantation; E2 and E3, rain-fed; E1, E4, and E5, fresh groundwater irrigated; E6, E7, and E8, brackish groundwater irrigated. Insets show locations of Rajasthan in India and of referenced towns/cities in Rajasthan. 

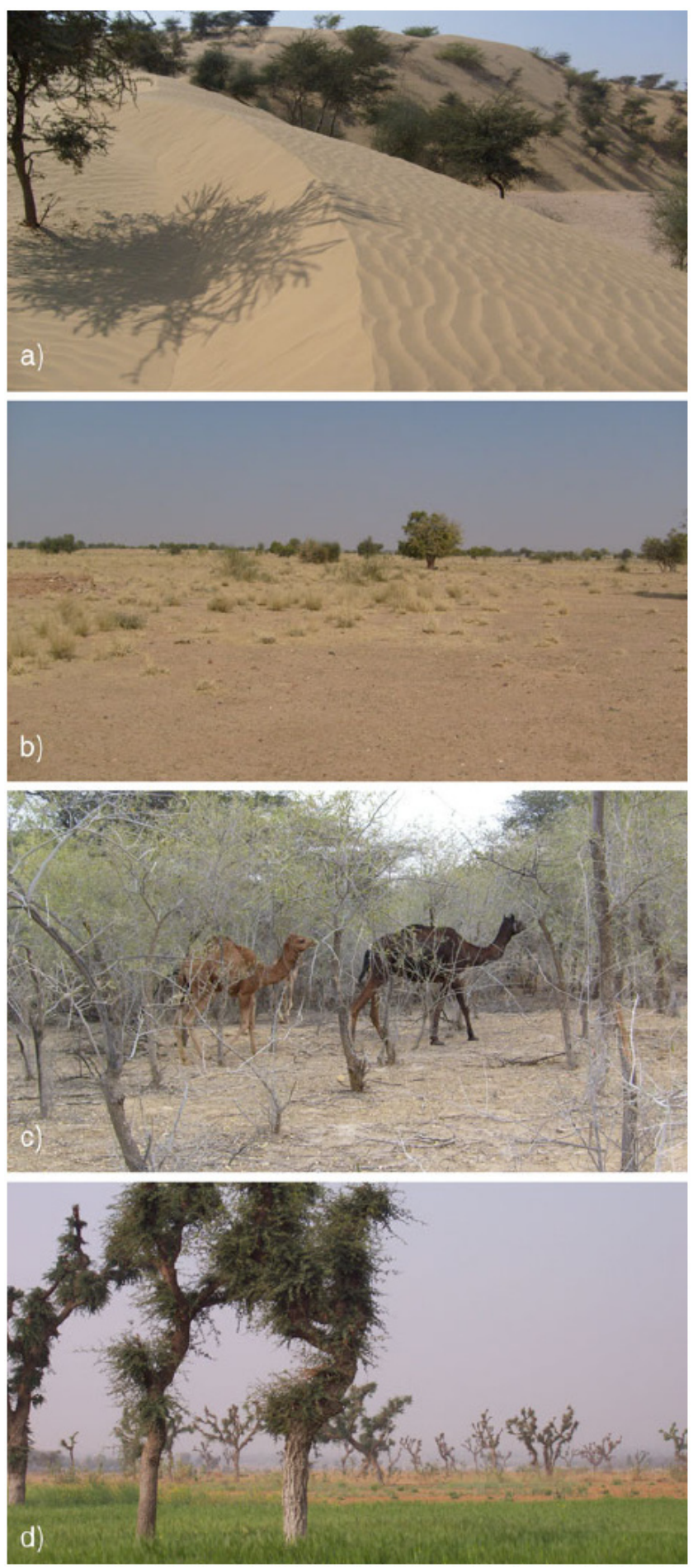

Figure 2. Photographs of borehole sites, a W5, modern dune, b W11, interdune, c W7, interdune plantation, and d E8, high-salinity groundwater irrigation.

(Figure 1). Surface sediments consist of Quaternary-age loess sediments and residual sand dunes (Wasson et al. 1983; SRSA 1999). Most small streams in the area, which originate in the northeast, drain toward the west to a large saline playa lake (Lake Sambhar). The moderately thick unsaturated zone in the area consists of mostly sand and silt, with occasional calcrete. Water-table depths generally range from 20 to $40 \mathrm{~m}$ (SRSA 1999). The aquifers consist of unconsolidated Quaternary sediments and underlying metasediments. Recent groundwater development in the area has led to overdraft and rapid water-table declines of 3-7 $\mathrm{m}$ between 1984 and 1997 (SRSA 1999). However, in some localities, such as near Lake Sambhar and near the city of Jaipur, the water table fell as much as $12 \mathrm{~m}$ in the 1990s (SRSA 1999).

The climate is semiarid (UNEP 1991), with mean annual precipitation of $604 \pm 229 \mathrm{~mm} /$ year at Jaipur meteorological station (1868-2000 omitting 1870, 1873, 1969, 1973, 1976-1978, 1981; source: GHCN, Vose et al. 1998). Most $(66 \%)$ precipitation occurs during July and August (Figure 3). In Jaipur, mean temperature ranges from $8.3^{\circ} \mathrm{C}$ (January) to $40.6^{\circ} \mathrm{C}$ (May), and PET ranges from 1,700 to $1,800 \mathrm{~mm} /$ year.

Natural vegetation in the study area consisted of shrubs and grasses. Much of the area has been cultivated since prehistoric times and includes nonirrigated (rain-fed) and irrigated cropland (Figure 2d). Because nomadic tribes and settlers have inhabited this area for thousands of years (Sharma 1966), it is very difficult or impossible to identify any region that has not been cultivated previously. Currently irrigated sites have had periods of rainfed agriculture in the past. Whereas irrigated areas yield two to three different crops during a year, rain-fed crops are produced only during the monsoon season. Crops are mostly wheat, pearl millet, barley, and malt.

\section{Precipitation chemistry}

Monitoring stations for precipitation chemistry are limited and are maintained by the Indian Background Air Pollution Monitoring Network (BAPMoN). The most comprehensive long-term (1976-1987) published measurements of wet-only deposition are available for the station in Jodhpur $\left(26^{\circ} 18^{\prime} \mathrm{N}, 73^{\circ} 01^{\prime} \mathrm{E}\right)$, midway between the two study areas ( $\sim 300 \mathrm{~km}$ from Jaipur and Jaisalmer; Mukhopadhyay et al. 1992).

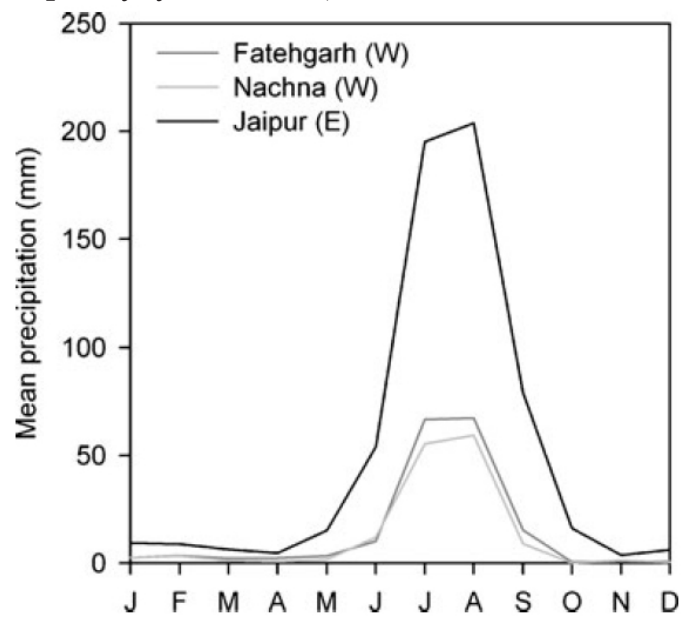

Figure 3. Mean monthly precipitation measured at two locations near the western $(W)$ study area (Fatehgarh and Nachna) and at the eastern (E) study area (Jaipur) based on data from 1929 to 1967 (Fatehgarh), 1930 to 1966 (Nachna), and 1868 to 2000 (Jaipur). 
Volume-weighted mean annual $\mathrm{Cl}$ concentration in precipitation is $2.0 \pm 0.62 \mathrm{mg} / \mathrm{L}$. Calculations for the $\mathrm{CMB}$ require information on $\mathrm{Cl}$ input from precipitation and dry fallout (bulk precipitation); however, no data are available to suggest how to modify wet-only precipitation input for dry deposition. The value of $2 \mathrm{mg} / \mathrm{L}$ was, therefore, used for CMB calculations as a lower bound. Mean precipitation at Jodphur for 1976-1987 (380 $\mathrm{mm})$ is also between precipitation values at both study sites $(165 \mathrm{~mm}$, Jaisalmer, and $600 \mathrm{~mm}$, Jaipur); however, the $\mathrm{Cl}$ deposition was not modified by precipitation amount because of insufficient information. BAPMon data also include information on $\mathrm{SO}_{4}$ in precipitation $(1.9 \pm 1.8 \mathrm{mg} / \mathrm{L}$; Mukhopadhyay et al. 1992).

\section{Methods \\ Field Methods}

Boreholes were drilled in January and February and sediment samples collected in the western study area near Jaisalmer in 2007 and in the eastern study area near Jaipur in 2008 (Figure 1, Table 1). The western study area includes two boreholes in dunes, one in an interdune setting and one in an interdune setting with a plantation adjacent to an irrigation canal (Figure 1). Three additional boreholes were drilled in interdune settings but were not sufficiently deep (1.2-2.4 m) because of shallow bedrock to provide useful information for the study's objectives. The eastern study area includes three boreholes in currently rain-fed sites and five in currently irrigated sites. Borehole depths range from 3.0 to $14.6 \mathrm{~m}$, with deeper boreholes mostly in the eastern site.

In the western study area, sediment samples were obtained using a hollow-stem hand auger with interchangeable $1.5-\mathrm{m}$ aluminum rods and $70-\mathrm{mm}$-diameter opening (Dormer Engineering, Australia). In the eastern study area, a mechanized hollow-stem rotary drill rig with a 150-mm-diameter opening, generally used for tube-well installation, was used to collect sediment samples. From each of the drilling sites, past and present land-use data, water-table depth, and other relevant information were collected from local sources.

Bulk sediment samples of $\sim 200 \mathrm{~g}$ were collected at $\sim 0.15$-m-depth intervals for the top $1.5-\mathrm{m}, 0.3-\mathrm{m}$ intervals for 1.5-4.6 m, 0.9-m intervals for 4.6-11 m, and 1.8-m intervals to maximum borehole depth. Samples were immediately placed in air-tight plastic cups, sealed with parafilm or plastic tape, and then sealed in air-tight polyethylene bags to minimize sample drying. Groundwater samples were collected from three irrigated sites in the eastern study area. Groundwater samples were stored in 125-ml HDPE bottles without any preservative. Sediment and groundwater samples were shipped to the University of Texas at Austin for analyses.

\section{Laboratory Methods}

Water-extractable concentrations of anions $\left(\mathrm{Cl}, \mathrm{SO}_{4^{\prime}} \mathrm{NO}_{3^{\prime}}\right.$ and $\mathrm{PO}_{4}$ ) were analyzed in water leached from 211 unsaturated zone sediment samples. About $40 \mathrm{ml}$ of double deionized water was added to $\sim 25 \mathrm{~g}$ of soil in centrifuge tubes. The mixture was placed in a reciprocal shaker for 4 $\mathrm{h}$ and then centrifuged at 7,000 rpm for $45 \mathrm{~min}$ to separate water from sediment. The supernatant was filtered $(0.2 \mu \mathrm{m})$ and stored at $4^{\circ} \mathrm{C}$ before being analyzed by ion chromatography (Dionex ICS2000). Residual sediments in the centrifuge tubes were then oven dried at $105^{\circ} \mathrm{C}$ for $48 \mathrm{~h}$ to determine gravimetric water content. Water-extractable ion concentrations are expressed on a mass basis as mg of ion per $\mathrm{kg}$ of dry soil -supernatant concentration $\times$ extraction ratio (g water/g soil) and divided by water density. Ion concentrations are also expressed as $\mathrm{mg}$ of ion per liter of

Table 1. Borehole concentration and inventory values for chloride, sulfate, nitrate $(\mathrm{N})$, and phosphate $(\mathrm{P})$. Concentration values represent depthweighted means, and inventory values are normalized by indicated depth interval. W2, W5: dunes; W11: interdune; W7: interdune plantation. Setting Depth WC Mean concentration Mean concentration Normalized inventory Normalized inventory

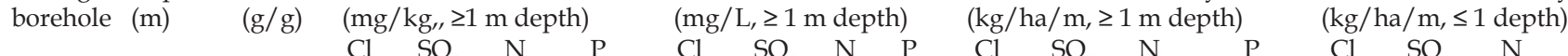

\begin{tabular}{|c|c|c|c|c|c|c|c|c|c|c|c|c|c|c|c|c|c|c|}
\hline \multicolumn{19}{|c|}{ Jaisalmer } \\
\hline W2 & 4.6 & 0.01 & 1.0 & 1.9 & 0.15 & 0.07 & - & - & - & - & 16 & 31 & 2.4 & 1.2 & 13 & 31 & 5.5 & 1.6 \\
\hline W5 & 11.0 & 0.00 & 0.6 & 1.2 & 0.42 & 0.11 & - & - & - & - & 10 & 19 & 6.7 & 1.7 & 17 & 38 & 20 & 1.9 \\
\hline W11 & 3.0 & 0.01 & 1.6 & 2.1 & $<0.01$ & $<0.01$ & - & - & - & - & 25 & 33 & $<0.24$ & $<0.24$ & 28 & 58 & 5.4 & 0.43 \\
\hline $\begin{array}{l}\text { W7 } \\
\text { aipur, }\end{array}$ & $\begin{array}{l}4.6 \\
\text { in-fed }\end{array}$ & 0.02 & 30 & 23 & 0.85 & 0.07 & - & - & - & - & 480 & 370 & 14 & 1.2 & 64 & 66 & 28 & 2.1 \\
\hline E2 & 10.0 & 0.05 & 1.5 & 2.0 & 0.05 & 0.11 & 29 & 58 & 1.4 & 2.6 & 25 & 32 & 0.85 & 1.7 & 48 & 36 & 12 & 2.2 \\
\hline $\begin{array}{l}\text { E3 } \\
\text { aipur, }\end{array}$ & $\begin{array}{l}6.3 \\
\text { igated }\end{array}$ & $\begin{array}{l}0.05 \\
\text { sh gr }\end{array}$ & $\begin{array}{c}0.6 \\
\text { hdwat }\end{array}$ & $\begin{array}{l}1.0 \\
\mathrm{er})\end{array}$ & 0.04 & 0.88 & 13 & 20 & 0.7 & 16 & 10 & 15 & 0.57 & 14.0 & 26 & 21 & 23 & 36 \\
\hline E5 & 12.7 & 0.06 & 4.1 & 4.4 & 2.7 & 0.12 & 86 & 90 & 57 & 3.5 & 66 & 70 & 43 & 2.0 & 95 & 61 & 60 & 20 \\
\hline E1 & 11.0 & 0.09 & 6.3 & 2.8 & 1.6 & 0.10 & 68 & 33 & 17 & 1.0 & 100 & 44 & 25 & 1.5 & 47 & 24 & 64 & 38 \\
\hline $\begin{array}{l}\text { E4 } \\
\text { aipur, }\end{array}$ & $\begin{array}{l}13.2 \\
\text { gated }\end{array}$ & $\begin{array}{l}0.11 \\
\text { ackish }\end{array}$ & $\begin{array}{l}7.8 \\
\text { ound }\end{array}$ & $\begin{array}{c}4.8 \\
\text { vater) }\end{array}$ & 1.2 & 0.07 & 66 & 42 & 9.5 & 0.78 & 120 & 77 & 19 & 1.1 & 170 & 100 & 160 & 7.9 \\
\hline E6 & 6.0 & 0.05 & 210 & 58 & 0.34 & 0.05 & 3,900 & 1,100 & 6.2 & 1.1 & 3,100 & 860 & 5.8 & 0.71 & 1,500 & 560 & 49 & 3.8 \\
\hline E7 & 14.6 & 0.06 & 18 & 6.5 & 0.34 & 0.03 & 280 & 110 & 5.5 & 0.55 & 290 & 100 & 5.4 & 0.55 & 190 & 110 & 98 & 3.0 \\
\hline E8 & 14.6 & 0.06 & 63 & 9.5 & 0.27 & 0.02 & 970 & 190 & 3.7 & 0.40 & 3,100 & 470 & 13 & 1.1 & 4,400 & 590 & 170 & 3.7 \\
\hline
\end{tabular}

WC water content; $\mathrm{N} \mathrm{NO}_{3}-\mathrm{N} ; \mathrm{P} \mathrm{PO}_{4}^{--\mathrm{P}}$ 
pore water by dividing $\mathrm{mg} / \mathrm{kg}$ by gravimetric water content and multiplying by water density. Because of potential water loss during sample collection and processing, ionic concentrations on a mass basis (mg ion/kg dry soil) are considered more reliable than concentrations expressed on a pore water volume basis (mg ion/L soil water). Water loss during sample collection or processing would result in overestimation of ionic concentrations as $\mathrm{mg} / \mathrm{L}$. Salt inventories (kg/ha) were calculated by multiplying depth-weighted salt concentrations $(\mathrm{mg} / \mathrm{kg})$ by interval thickness $(\mathrm{m})$, soil bulk density $\left(\mathrm{kg} / \mathrm{m}^{3}\right)$, and a unit conversion factor of $10^{4}\left(\mathrm{~m}^{2} / \mathrm{ha}\right)$.

\section{Data analyses}

Previous studies have estimated drainage or percolation rates below the root zone or recharge to groundwater using the CMB method (Allison and Hughes 1983). According to the CMB method in natural systems and rain-fed agricultural systems, percolation (Pe) or recharge $(\mathrm{R})$ rates are calculated as follows:

$$
\begin{aligned}
P \times \mathrm{Cl}_{\mathrm{p}} & =\mathrm{Pe} \times \mathrm{Cl}_{\mathrm{uz}} \text { or } R \times \mathrm{Cl}_{\mathrm{uz}}, \\
\mathrm{Pe} & =R=\frac{P \times \mathrm{Cl}_{\mathrm{p}}}{\mathrm{Cl}_{\mathrm{uz}}}
\end{aligned}
$$

where $P$ is precipitation, $\mathrm{Cl}_{\mathrm{p}}$ is $\mathrm{Cl}$ concentration in bulk precipitation (wet and dry fallout), and $\mathrm{Cl}_{\mathrm{uz}}$ is $\mathrm{Cl}$ concentration in unsaturated zone pore water. The CMB approach requires unsaturated zone $\mathrm{Cl}$ concentrations in mass/volume, usually reported in $\mathrm{mg} / \mathrm{L}$. If samples undergo drying during collection or processing, $\mathrm{Cl}_{\mathrm{uz}}$ may be overestimated, and calculated recharge rates would be underestimated. If $\mathrm{Cl}$ is added to the system in irrigation water, then irrigation rate $(\mathrm{I}, \mathrm{mm} / \mathrm{year})$ and $\mathrm{Cl}$ concentration in irrigation water $\left(\mathrm{Cl}_{\mathrm{I}}\right)$ need to be included as follows:

$\mathrm{Pe}=R=\frac{P \times \mathrm{Cl}_{\mathrm{p}}+I \times \mathrm{Cl}_{\mathrm{I}}}{\mathrm{Cl}_{\mathrm{uz}}}$

Water fluxes were calculated for each depth interval, and depth-weighted averages were calculated over prespecified depth intervals. There are a number of assumptions required to apply the $\mathrm{CMB}$ approach, including onedimensional (1-D), vertical downward, piston-type flow, and no subsurface sources or sinks for $\mathrm{Cl}$. The geochemically conservative behavior of $\mathrm{Cl}$ and the high solubility of halite result in $\mathrm{Cl}$ being widely used for recharge calculations.

Mass balance calculations can be applied to other tracers to estimate recharge if the tracer input can be quantified and the tracer behaves conservatively, i.e., no subsurface sources or sinks. Sulfate has not previously been used to estimate recharge because there are other sources of $\mathrm{SO}_{4}$, such as gypsum dissolution, and $\mathrm{SO}_{4}$ can sorb onto sediments (Scanlon et al. 2009). If $\mathrm{SO}_{4}$ input from precipitation is known and there are no subsurface sources or sinks for $\mathrm{SO}_{4}$, a similar mass balance expression can be written for estimating percolation or recharge rates:

$$
\begin{gathered}
P \times \mathrm{SO}_{4 \mathrm{p}}+I \times \mathrm{SO}_{4 \mathrm{I}}=\mathrm{Pe} \times \mathrm{SO}_{4 \mathrm{uz}} \text { or } R \times \mathrm{SO}_{4 \mathrm{uz}}, \\
\mathrm{Pe}=R=\frac{P \times \mathrm{SO}_{4 \mathrm{p}}+I \times \mathrm{SO}_{4 \mathrm{I}}}{\mathrm{SO}_{4 \mathrm{uz}}}
\end{gathered}
$$

Comparison of percolation/recharge rates from $\mathrm{SO}_{4}$ with those based on $\mathrm{Cl}$ provides the best test of whether $\mathrm{SO}_{4}$ can be used to estimate percolation/recharge. Uncertainties in $\mathrm{Cl}$ and $\mathrm{SO}_{4}$ inputs (precipitation or salt concentrations in precipitation) would be linearly translated into uncertainties in recharge rates because the equations are linear. The time $\left(t\right.$, year) required to accumulate $\mathrm{Cl}$ or $\mathrm{SO}_{4}$ in the subsurface was estimated by dividing the cumulative mass of $\mathrm{Cl}$ or $\mathrm{SO}_{4}$ in the profile by $\mathrm{Cl}$ or $\mathrm{SO}_{4}$ input:

$t=\frac{\sum \mathrm{Cl}_{\mathrm{uz}} \rho_{\mathrm{b}} \mathrm{dz}}{P \mathrm{Cl}_{\mathrm{P}}+I \mathrm{Cl}_{\mathrm{I}}}=\frac{\sum \mathrm{SO}_{4 \mathrm{uz}} \rho_{\mathrm{b}} \mathrm{dz}}{P \mathrm{SO}_{4 \mathrm{P}}+I \mathrm{SO}_{4 \mathrm{I}}}$

where subscripts $u z, P$, and $I$ refer to concentrations of $\mathrm{Cl}$ or $\mathrm{SO}_{4}$ in unsaturated zone pore water $(\mathrm{mg} / \mathrm{kg})$, in bulk precipitation (wet and dry fallout; $\mathrm{mg} / \mathrm{L}$ ), and in irrigation water $(\mathrm{mg} / \mathrm{L})$, respectively, $\rho_{\mathrm{b}}$ is soil dry bulk density $\left(\mathrm{kg} / \mathrm{m}^{3}\right), \mathrm{dz}$ is depth interval, $P$ is precipitation $(\mathrm{mm} /$ year), and $I$ is irrigation rate (mm/year). In natural and rain-fed cropland systems, the only $\mathrm{Cl}$ or $\mathrm{SO}_{4}$ input is from bulk precipitation. It is sometimes difficult to determine inputs in irrigated profiles. Omission of an input, such as irrigation, in irrigated profiles would result in overestimation of accumulation time.

\section{Numerical modeling}

To provide an independent comparison with CMBbased recharge estimates, water flux through the unsaturated zone was simulated using the Hydrus 1-D water flow model (Simunek et al. 2005), combined with atmospheric forcing boundary conditions from land surface model outputs and literature-based parameter values. This approach is suitable for testing whether CMB calculations are consistent with available climate, vegetation, and soil information; however, considering the paucity of site-specific field parameters or calibration data, modeled percolation or recharge rates should be viewed as preliminary estimates only. Model geometry consisted of a 1-D 3-m-deep profile discretized into 30-mm intervals. Initial conditions were based on measured water content of 0.02 $\mathrm{m}^{3} / \mathrm{m}^{3}$ in the western study area and $0.05 \mathrm{~m}^{3} / \mathrm{m}^{3}$ in the eastern study area. Typical soil water retention parameters for clean sand (van Genuchten parameters: saturated water content, $0.43 \mathrm{~m}^{3} / \mathrm{m}^{3}$; residual water content, 0.02 $\mathrm{m}^{3} / \mathrm{m}^{3} ; \mathrm{a}, 0.145 / \mathrm{cm} ; n, 2.68$; and saturated hydraulic conductivity, 7.13 m/day; Carsel and Parrish 1988) were used to describe hydraulic properties of the sediment. Upper boundary conditions were provided by reference evapotranspiration $\left(\mathrm{ET}_{\text {ref }}\right)$ and precipitation $(P)$ outputs from the 
Global Land Data Assimilation System (GLDAS) at 3-h intervals from February 24, 2000, through 2007 (Rodell et al. 2004). Leaf area index for partitioning $\mathrm{ET}_{\text {ref }}$ into potential evaporation and potential transpiration was estimated from the literature (White et al. 2000; Asner et al. 2003). Root-water uptake was assumed to decrease exponentially with depth (Zeng 2001). Parameters for determining reduction of root-water uptake due to water stress were chosen to be consistent with xylem cavitation ranges for xeric vegetation-anaerobiosis potential: 0.0 to -0.3 $\mathrm{m}$; optimal potential, -0.3 to $-10 \mathrm{~m}$; wilting point, $-500 \mathrm{~m}$ (western site) and $-150 \mathrm{~m}$ (eastern site; Feddes et al. 1978; Pockman and Sperry 2000). Percolation below $3 \mathrm{~m}$ was considered representative of potential recharge and used to calculate an average annual recharge rate.

\section{Results and discussion}

Although the number of boreholes drilled in each study area is limited and the range in climate and land-use conditions varies widely between western and eastern study areas, some general trends emerge. A plot of $\mathrm{SO}_{4}$ inventories versus $\mathrm{Cl}$ inventories below the root zone (1 $\mathrm{m}$ depth) shows a grouping of profiles in the various settings (Figure 4). Although $\mathrm{SO}_{4}$ may often be derived from dissolution of gypsum and other minerals, $\mathrm{SO}_{4}$ in these study areas seems to be derived primarily from precipitation and irrigation inputs. Profiles in dune/interdune settings in the western study area generally have low $\mathrm{SO}_{4}$ and $\mathrm{Cl}$ inventories, with the exception of the profile beneath the plantation, which has higher inventories. Cultivated sites in the eastern study area beneath rain-fed cropland have inventories similar to those in dune/interdune settings in the western study area because precipitation provides the only salt input to the system. Profiles beneath sites that were irrigated at some time in the eastern study area have higher $\mathrm{SO}_{4}$ and $\mathrm{Cl}$ inventories, particularly profiles that have been irrigated with brackish groundwater.

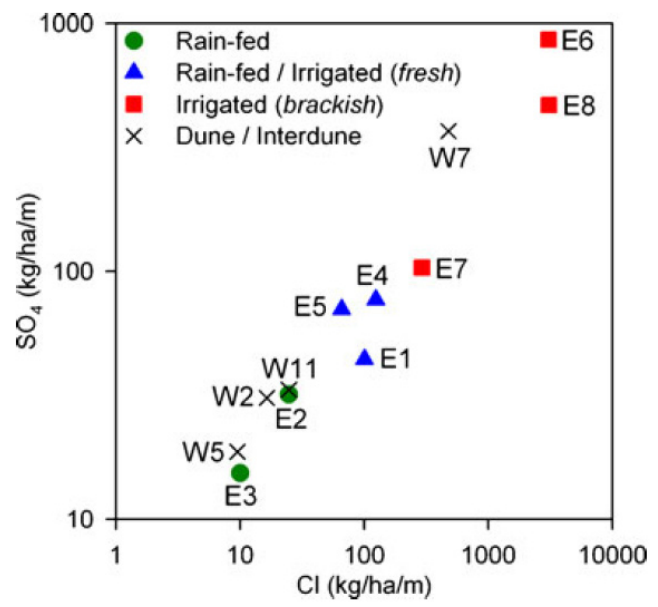

Figure 4. Relationship between chloride and sulfate inventories normalized by depth for dune/interdune settings in the western study area and rain-fed and irrigated sites in the eastern study area.

\section{Recharge rates and salt and nutrient inventories in the western study area profiles}

Profiles in the western study area near Jaisalmer are sandy (mean sand content 94-99\%; Table 2). Dune profiles (W2 and W5) are characterized by extremely low water contents, with mean values for profiles of $0.00-0.01 \mathrm{~g} / \mathrm{g}$ below $1 \mathrm{~m}$ depth (Figure 5, Table 1). Although these low water contents may be natural, the extremely low values suggest that they may have been impacted by sample drying during collection or processing because of the extreme sandy nature of the sediments (W5, 99\% sand). Mean Cl concentrations and inventories $\geq 1 \mathrm{~m}$ depth are low $(0.6$ and $1.0 \mathrm{mg} / \mathrm{kg} ; 10$ and $16 \mathrm{~kg} / \mathrm{ha} / \mathrm{m}$ ) in dune settings (Figure 5,Table 1). Concentrations of $\mathrm{Cl}$ are low throughout the profiles $(0.3-3.7 \mathrm{mg} / \mathrm{kg}$ ), with no well-defined peaks (Figure 5). The low water contents would result in overestimation of $\mathrm{Cl}$ concentrations in $\mathrm{mg} / \mathrm{L}$ if they were an artifact of sample drying. Dunes are sparsely vegetated (Figure 2a), and the time required to accumulate $\mathrm{Cl}$ in dune profiles is 18 and 34 years (Table 3). Dune/interdune areas have large topographic relief $(\sim 35 \mathrm{~m})$, which makes it difficult to apply the CMB 1-D analysis to subsurface recharge calculations. However, the uniformly low $\mathrm{Cl}$ concentrations indicate depth-weighted mean recharge rates $\geq 1 \mathrm{~m}$ below surface of 2.7 and $3.2 \mathrm{~mm}$ /year, representing $2 \%$ of longterm precipitation (Table 3 ). These recharge rates provide a lower bound on actual recharge rates if sediment samples were affected by drying. Inventories and concentrations of $\mathrm{SO}_{4}$ are also low throughout the profiles, indicating that $\mathrm{SO}_{4}$ is likely of meteoric origin (Figure 5, Table 1). Concentrations of $\mathrm{SO}_{4}$ were also used to estimate recharge rates using a mass balance approach (Equation 3), similar to that for $\mathrm{Cl}$. Calculated recharge rates based on $\mathrm{SO}_{4}(1.3$ and $1.4 \mathrm{~mm}$ /year) are slightly lower than those based on $\mathrm{Cl}$ (Table 3).

The interdune profile (W11; $3 \mathrm{~m}$ deep) is shallower than the dune profiles ( 4.6 and $11 \mathrm{~m}$ ). Depths of interdune profiles were restricted because of bedrock. Soil texture, water contents, and $\mathrm{Cl}$ concentrations in the interdune profile are similar to those in dune profiles (Figure 5, Tables 1 and 2). Chloride accumulation time to the base of the profile $(3 \mathrm{~m}$ depth) is 23 years, similar to values for dune profiles. Estimated recharge rate is $5.6 \mathrm{~mm} /$ year ( $3 \%$ of precipitation), slightly higher than those estimated for dunes (Table 3 ).

Concentrations and inventories of $\mathrm{NO}_{3}$ and $\mathrm{PO}_{4}$ within and below the top meter are all low in both dune and interdune settings, indicating low nutrient levels in these sandy soils and lack of $\mathrm{N}$ fixation by sparse vegetation or mineralization of soil organic nitrogen (Figure 5, Table 1). The nutrient inventory is slightly higher in the upper meter of the interdune setting.

Profile W7 is also in an interdune setting where a plantation was developed adjacent to an irrigation canal (Figure $2 c$ ). The plantation was established $\sim 30$ years ago to minimize transport of sand into the canal. This profile differs from other dune and interdune profiles in having higher $\mathrm{Cl}$ concentrations (mean $30 \mathrm{mg} / \mathrm{kg}$ ) and inventories (480 $\mathrm{kg} / \mathrm{ha} / \mathrm{m}$; Figure 5, Table 1). The profile extends only to a depth of $4.6 \mathrm{~m}$, and the peak $\mathrm{Cl}$ concentration $(49 \mathrm{mg} / \mathrm{kg})$ 
Table2. Depth-weighted meansand, silt, and clay formeasured profiles

$\begin{array}{llll}\text { Borehole } & \text { Sand }(\%) & \text { Silt }(\%) & \text { Clay }(\%) \\ \text { W5 } & 99 & 0 & 1 \\ \text { W11 } & 94 & 4 & 2 \\ \text { W7 } & 95 & 3 & 2 \\ \text { E2 } & 83 & 10 & 7 \\ \text { E3 } & 94 & 3 & 3 \\ \text { E1 } & 84 & 10 & 6 \\ \text { E6 } & 72 & 19 & 9 \\ \text { E7 } & 71 & 19 & 10\end{array}$

is at $2.1 \mathrm{~m}$ depth. A high correlation between $\mathrm{Cl}$ and $\mathrm{SO}_{4}$ $(r=0.95)$ suggests a common source. Increased water uptake by trees would increase $\mathrm{Cl}$ concentrations in $\mathrm{mg} / \mathrm{L}$ but should not affect the $\mathrm{Cl}$ mass concentration $(\mathrm{mg} / \mathrm{kg})$. High $\mathrm{Cl}$ and $\mathrm{SO}_{4}$ mass concentrations, therefore, indicate that the site was probably irrigated to establish the plantation, although there is currently no evidence of irrigation. Concentrations and inventories of $\mathrm{NO}_{3}$ and $\mathrm{PO}_{4}$ are a little higher in this profile than other profiles in this study area and may reflect inputs from irrigation water (Table 1).

\section{Modeling of recharge in the western study area}

Unsaturated zone water fluxes were simulated in sandy soils to represent water movement in sandy dune sites. The simulation period is from February 24, 2000 through 2007, which is the period for which GLDAS forcing is available (Rodell et al. 2004). Mean annual precipitation (MAP) for the simulation period $(131 \mathrm{~mm})$ is similar to long-term MAP (155-178 mm/year; 1,930 to mid-1960s); therefore, this precipitation record should be representative of long-term conditions. A mean recharge rate of $22 \mathrm{~mm} /$ year was simulated for nonvegetated conditions, which provides an upper bound on recharge that results from climatic forcing. Sparse vegetation was approximated by a maximum leaf area index of 1 , and sensitivity analyses were conducted to assess impacts of varying rooting depth. Simulated rooting depths were 0.5, $1.0,1.5$, and $2.0 \mathrm{~m}$, and resultant recharge rates were 17 , $4.6,0.9$, and $0.0 \mathrm{~mm} /$ year, respectively. Mean recharge rates resulted from averaging over the 7-year simulation period; however, recharge occurred only in 2007. The CMB-based recharge estimates of 3-6 mm/year are generally consistent with simulated recharge for the root-
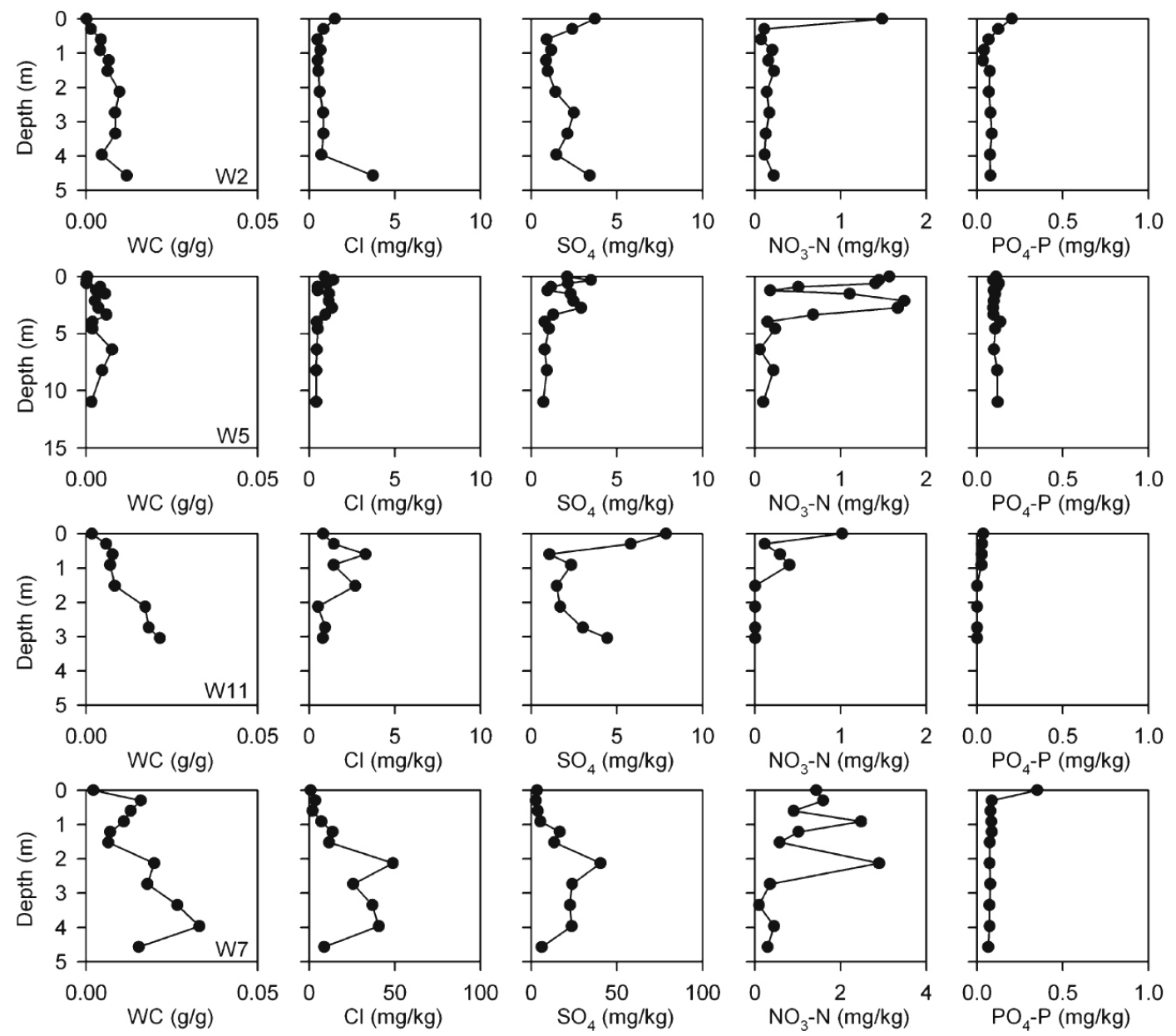

Figure 5. Representative water content $(W C)$, chloride, sulfate, nitrate $(N)$, and phosphate $(P)$ profiles for boreholes located in the western study area: W2 and W5, dune; W11, interdune; and W7, interdune plantation. Concentrations in $\mathrm{mg} / \mathrm{L}$ are not shown because measured water contents may not be reliable. For location of boreholes, see Figure 1, and for photos of selected borehole locations, see Figure 2. 
Table 3. Chloride accumulation times $(C M B$ age $)$ based on entire profile, chloride mass balance $(C M B)$ and sulfate mass balance $(S M B)$ annual recharge flux, and corresponding percentage of mean annual precipitation $(P)$ for borehole profiles in the western $(W)$ and eastern $(E)$ study areas based on concentrations below $1 \mathrm{~m}$ depth except as noted.

\begin{tabular}{|c|c|c|c|c|c|c|}
\hline Borehole & Land use & CMB age (years) & $\begin{array}{l}\text { CMB flux } \\
\text { (mm/yr) }\end{array}$ & $\%$ of $\mathrm{P}$ & $\begin{array}{l}\text { SMB flux } \\
\text { (mm/yr) }\end{array}$ & $\%$ of $\mathrm{P}$ \\
\hline W2 & Dune & 18 & 3.2 & 1.9 & 1.4 & 0.85 \\
\hline W5 & Dune & 34 & 2.7 & 1.6 & 1.3 & 0.79 \\
\hline W11 & Interdune & 23 & 5.6 & 3.4 & 2.2 & 1.3 \\
\hline E2 & Rain-fed & 23 & 61 & 10 & 44 & 7.3 \\
\hline E3 & Rain-fed & 6.7 & 94 & 16 & 72 & 12 \\
\hline $\mathrm{E}^{\mathrm{a}}$ & Rain-fed & 8.0 & 120 & 20 & 17 & 2.8 \\
\hline $\mathrm{E} 8^{\mathrm{b}}$ & Rain-fed & 28 & 50 & 8.3 & 47 & 7.8 \\
\hline \multicolumn{7}{|c|}{ Irrigated with fresh groundwater } \\
\hline E5 & Irrigated & 72 & 98 & 16 & 39 & 6.5 \\
\hline E1 & Irrigtaed & 87 & 28 & 4.6 & 47 & 7.8 \\
\hline E4 & Irrigated & 140 & 18 & 3.0 & 28 & 4.7 \\
\hline \multicolumn{7}{|c|}{ Irrigated with brackish groundwater } \\
\hline E6 & Irrigated & 7,100 & 0.3 & 0.05 & 1.5 & 0.25 \\
\hline E7 & Irrigated & 350 & 5.6 & 0.93 & 15 & 2.5 \\
\hline E8 & Irrigated & 1,500 & 33 & 5.5 & 43 & 7.2 \\
\hline
\end{tabular}

Values are calculated using mean annual precipitation of $165 \mathrm{~mm} /$ year for the western study area and $600 \mathrm{~mm} /$ year for the eastern study area, with $2.0 \mathrm{mg} / \mathrm{L} \mathrm{Cl}$ and $1.9 \mathrm{mg} / \mathrm{L} \mathrm{SO} 4$ concentrations in precipitation for both study areas and assuming no irrigation inputs. Recharge rates for all irrigated profiles represent minimum values because irrigation input is omitted from the CMB and SMB calculations.

a Depth intervals representing rain-fed agriculture of currently irrigated profiles below $8.2 \mathrm{~m}$ depth.

b Depth intervals representing rain-fed agriculture of currently irrigated profiles 6.4-13.7 m depth interval.

zone depth of $\sim 1 \mathrm{~m}$. There are many limitations to this modeling exercise, including lack of site-specific data and short boundary condition time series. However, simulation results suggest that $\mathrm{CMB}$ recharge estimates should be reasonable.

\section{Recharge rates and salt and nutrient inventories in the eastern study area}

All sites sampled in the eastern study area near Jaipur are cultivated. Inventories of $\mathrm{Cl}$ and $\mathrm{SO}_{4}$ generally fall into three groups: lowest inventories under rain-fed cropland, moderate inventories under mixed rain-fed/irrigated cropland in an area of fresh groundwater, and highest inventories under rain-fed/irrigated cropland in an area of brackish groundwater (Figure 4, Table 1). Measured $\mathrm{Cl}$ and $\mathrm{SO}_{4}$ concentrations in groundwater samples in the area of fresh groundwater are low $(\mathrm{Cl}: 37$ and $66 \mathrm{mg} / \mathrm{L}$; $\mathrm{SO}_{4}: 5.6$ and $30 \mathrm{mg} / \mathrm{L}$ ), whereas concentrations were much higher in the area of brackish groundwater $(\mathrm{Cl}: 850$ and $\left.\mathrm{SO}_{4}: 170 \mathrm{mg} / \mathrm{L}\right)$. Elevated salinity in profiles in the area of brackish groundwater is attributed to proximity $(\leq 10$ $\mathrm{km}$ distant) to Lake Sambhar with its associated evaporite deposits and not to irrigation return flow.

Profiles under rain-fed cropland (E2 and E3) are generally sandy (mean sand content 83 and 94\%) (Table 2). Mean water contents are low $(0.05 \mathrm{~g} / \mathrm{g}$ for both profiles) (Table 1, Figure 6; ESM 1). Concentrations of $\mathrm{Cl}$ are low throughout the profiles, with no marked $\mathrm{Cl}$ peaks. Maximum $\mathrm{Cl}$ concentrations below $1 \mathrm{~m}$ depth are 15 and 170 $\mathrm{mg} / \mathrm{L}$. Times required to accumulate $\mathrm{Cl}$ in these profiles are 6.7 and 23 years, based on $\mathrm{Cl}$ input from precipitation $(2 \mathrm{mg} / \mathrm{L}$ ) and long-term MAP of $600 \mathrm{~mm} /$ year (Vose et al. 1998; Table 3). Accumulation times indicate that these two profiles represent entirely rain-fed conditions, according to landowner records of the timing of past irrigation practices at these sites. Calculated recharge rates for these two sites are high (61 and $94 \mathrm{~mm} /$ year, 10 and 16\% of MAP; Table 3). Concentrations of $\mathrm{SO} 4$ are similar to those of $\mathrm{Cl}$, and accumulation times and recharge rates based on $\mathrm{SO}_{4}$ are similar to those of $\mathrm{Cl}$, supporting a meteoric origin of $\mathrm{SO}_{4}$ and transport behavior similar to that of $\mathrm{Cl}$ in these sandy profiles (Table 3 ).

Two profiles are currently irrigated with fresh groundwater (E1 and E4), and another profile is currently rainfed, although most of the profile shows the effects of past irrigation (E5). Soil texture data, only available for E1, indicate that the profile is sandy (mean sand: $84 \%$; Table 2). Mean water contents $\geq 1 \mathrm{~m}$ are $0.06,0.09$, and $0.11 \mathrm{~g} / \mathrm{g}$, slightly higher than those under current, rain-fed cropland (Table 1, Figure 6; ESM 2). Inventories of $\mathrm{Cl}$ in these profiles are 66,100 , and $120 \mathrm{~kg} / \mathrm{ha} / \mathrm{m}, 3-12$ times higher than those of rain-fed profiles (Table 1). Maximum $\mathrm{Cl}$ concentrations in these irrigated profiles $\geq 1 \mathrm{~m}$ are 73, 140, and $310 \mathrm{mg} / \mathrm{L}$. Measured $\mathrm{Cl}$ concentrations in groundwater samples collected from irrigation wells are 37 and $66 \mathrm{mg} / \mathrm{L}$ at the two sites that are currently irrigated (E1 and E4; ESM 1); however, these measurements may not be representative of long-term mean $\mathrm{Cl}$ inputs in irrigation. Concentrations of $\mathrm{Cl}$ in pore water are less than the value in current irrigation water at some depths in profile E1, which is attributed to years of rain-fed agriculture interspersed with irrigation. Profile E4 has pore water $\mathrm{Cl}$ concentrations $(55-73 \mathrm{mg} / \mathrm{L})$ similar to the current $\mathrm{Cl}$ concentration in irrigation water $(66 \mathrm{mg} / \mathrm{L})$, which would reflect $100 \%$ inefficiency with respect to drainage if the system were continually irrigated. However, similarity in con- 

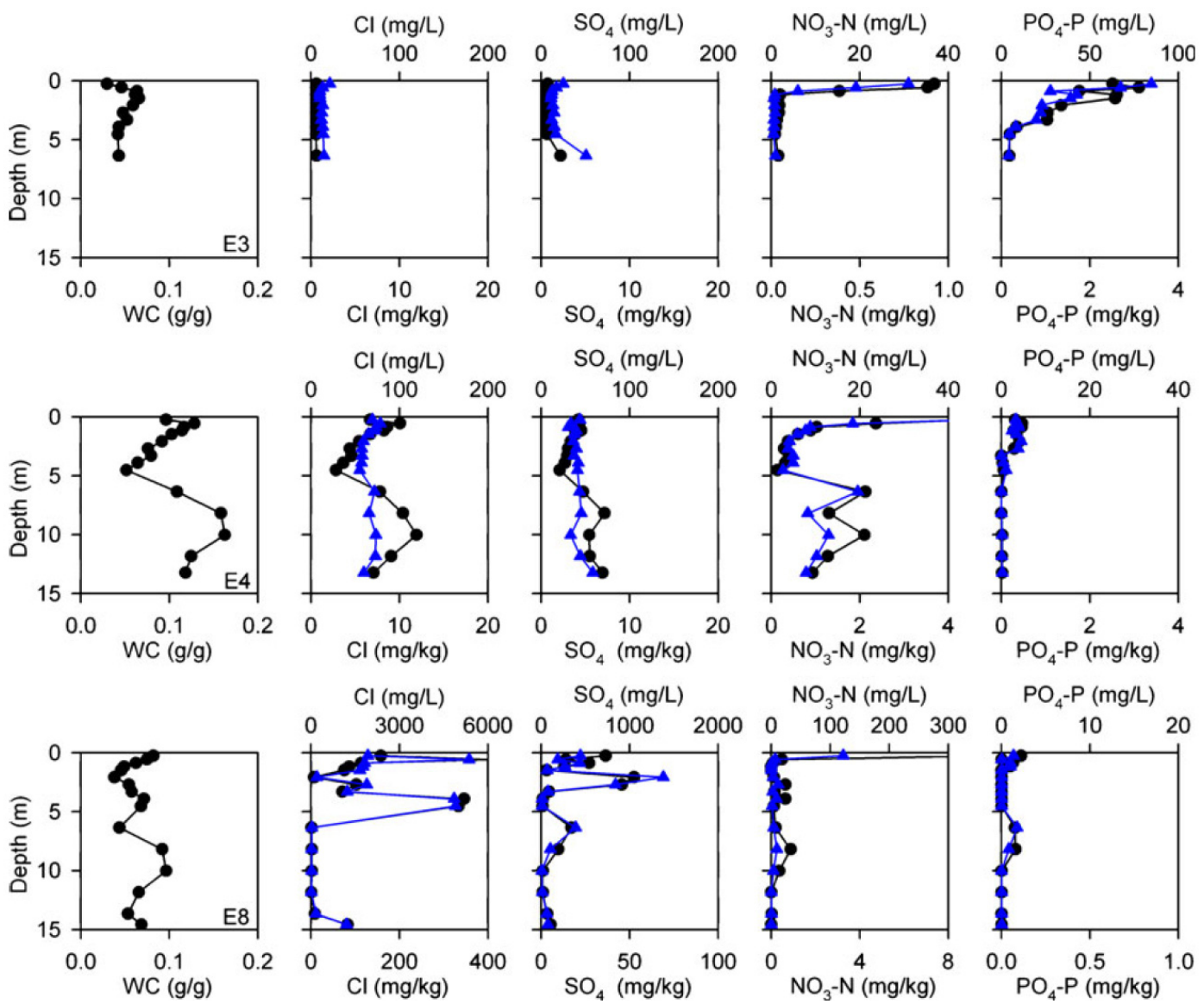

Figure 6. Representative water content $(W C)$, chloride, sulfate, nitrate- $N$, and phosphate- $P$ profiles for boreholes located in the eastern study area: E3, rain-fed; E4, irrigated with fresh groundwater; E8, irrigated with brackish groundwater. Black lines and circle symbols represent mg/ $\mathrm{kg}$ values. Blue lines and triangle symbols represent $\mathrm{mg} / \mathrm{L}$ values. For location of boreholes, see Figure 1.

centrations more likely reflects predominantly rain-fed agriculture interspersed with periodic irrigation. Uncertainties in irrigation application rates make estimating recharge rates difficult. Using $\mathrm{Cl}$ from precipitation alone provides lower bounds on recharge of 18,28 , and 98 $\mathrm{mm} /$ year (Table 3). Ignoring irrigation input provides an upper bound on $\mathrm{Cl}$ accumulation times of 72,87 , and 140 years. Profiles of $\mathrm{SO}_{4}$ are similar to those of $\mathrm{Cl}$ and result in similar recharge rates $(28,39$, and $47 \mathrm{~mm} /$ year) for precipitation input (Table 3). Because the flux and age equations are linear, adding irrigation with higher $\mathrm{Cl}$ concentrations than precipitation will proportionately increase the recharge rates and decrease the accumulation times.

In the area of brackish groundwater, all three profiles (E6, E7, and E8) have generally high $\mathrm{Cl}$ concentrations (mean 18, 63, and $210 \mathrm{mg} / \mathrm{kg}$, respectively), which indicates that they have been irrigated (Table 1). These irrigated profiles are not as sandy (E7: $71 \%$ and E6: $72 \%$ sand) as the other irrigated or rain-fed profiles (Table 2). Mean water contents in these profiles $\geq 1 \mathrm{~m}$ depthare moderate $(0.05,0.06$, and $0.06 \mathrm{~g} / \mathrm{g})$, similar to those in rain-fed profiles and slightly lower than those in other irrigated profiles (Table 1). Inventories of $\mathrm{Cl}(290,3,100$, and 3,100 kg/ $\mathrm{ha} / \mathrm{m}$ ) are much higher than all other profiles (Table 1). Peak $\mathrm{Cl}$ concentrations below the root zone $(1 \mathrm{~m})$ are 560,
4,900, and 6,000 mg/L and are found at depths of 1.2, 4.5, and $2.1 \mathrm{~m}$, respectively (Figure 6, ESM 3). Ignoring irrigation input to the $\mathrm{CMB}$ equation provides a minimum estimate of recharge rate and a maximum estimate of $\mathrm{Cl}$ accumulation time. Minimum recharge rates are 0.3, 5.6, and $33 \mathrm{~mm} /$ year (Table 3). Estimating actual recharge rates is difficult because of uncertainties in irrigation amounts and $\mathrm{Cl}$ concentrations in irrigation water. Chloride in the three profiles would require $350,1,500$, and 7,100 years to accumulate if precipitation provided the only input (Table 3). Groundwater sampled in one well in this brackish groundwater region near profile E8 has $850 \mathrm{mg} / \mathrm{L}$ $\mathrm{Cl}$ (ESM 1). Concentrations of $\mathrm{Cl}$ in $\mathrm{E} 7$ are $<850 \mathrm{mg} / \mathrm{L}$; therefore, $\mathrm{Cl}$ concentrations in irrigation water for this site should be $<850 \mathrm{mg} / \mathrm{L}$. Multiple $\mathrm{Cl}$ peaks in profile E8 suggest periods of high and low/no irrigation because soil water $\mathrm{Cl}$ concentrations at some depths are less than that of irrigation water if one assumes $845 \mathrm{mg} / \mathrm{L}$ for irrigation water $\mathrm{Cl}$ concentration (Figure 6). A zone of low $\mathrm{Cl}$ concentrations $(16-32 \mathrm{mg} / \mathrm{L})$ in profile E8 from 6.4 to $13.7 \mathrm{~m}$ depth is attributed to a period of rain-fed agriculture. Mean recharge rate for this zone is $50 \mathrm{~mm} /$ year, and the time period of rain-fed agriculture is estimated to be 28 years (Table 3 ). This recharge rate is similar to those under other rain-fed profiles (Table 3 ). 
At rain-fed sites, concentrations and inventories of $\mathrm{NO}_{3}$ and $\mathrm{PO}_{4}$ are highest in the root zone $(\leq 1 \mathrm{~m})$ and generally much lower at depth, indicating minimal leaching of these nutrients. Profile E3 is unusual in that high $\mathrm{PO}_{4}$ concentrations extend to $\sim 4 \mathrm{~m}$ depth, decreasing from 43 $\mathrm{mg} / \mathrm{L}$ at $1.2 \mathrm{~m}$ to $8 \mathrm{mg} / \mathrm{L}$ at $3.9 \mathrm{~m}$ depth (Figure 6). At sites irrigated with fresh groundwater (E1, E4, and E5), inventories of $\mathrm{NO}_{3}-\mathrm{N}$ are much higher than those beneath rain-fed agriculture, both within ( $\leq 1 \mathrm{~m}$ depth; 3-13 times higher) and below (22-75 times higher) the root zone (Table 1). Inventories of $\mathrm{NO}_{3}$ within the root zone are similar or slightly higher than those below the root zone (3-7 times), indicating some leaching of $\mathrm{NO}_{3}$ below the root zone. Inventories of $\mathrm{PO}_{4}$ are mostly in the root zone and are similar to or slightly higher than those under rain-fed cropland (Table 1). These differences in nutrient levels between irrigated and rain-fed agriculture are attributed to $\mathrm{NO}_{3}$ in irrigation water ( 9 and $13 \mathrm{mg} \mathrm{NO}-\mathrm{N} / \mathrm{L}$ in freshwater and $10 \mathrm{mg} \mathrm{NO}_{3}-\mathrm{N} / \mathrm{L}$ in brackish water, ESM 1 ) and fertilizer application in irrigated sites. In contrast, $\mathrm{PO}_{4}$ concentrations in irrigation water are low $(<0.01-0.03 \mathrm{mg}$ $\mathrm{PO}_{4}-\mathrm{P} / \mathrm{L}$ in all samples). At sites irrigated with brackish groundwater, $\mathrm{NO}_{3}-\mathrm{N}$ inventories in the root zone have a similar range to those under the other irrigated sites and are as much as 8 times lower below the root zone (Table 1). Inventories of $\mathrm{PO}_{4}$ are also lower within and generally below the root zone (Table 1).

The recharge estimates from this study provide some indication of how much groundwater can be extracted for irrigation without mining the aquifer. Recharge rates under rain-fed agriculture (50-120 mm/year), which are considered the most reliable, could support $300 \mathrm{~mm} /$ year of irrigation over $\sim 20-40 \%$ of cultivated land. These calculations address sustainability from the point of view of water quantity but do not assess water quality issues. Water quality should not be an issue in the area of fresh groundwater. Although brackish groundwater could degrade the soils because of salinity buildup, rotation with rain-fed agriculture should reduce this problem. Maintaining groundwater quality in terms of total salinity in the area of brackish groundwater is not an issue because it is already of low quality.

\section{Modeling of recharge in the eastern study area}

Unsaturated zone water fluxes were simulated for rainfed sites in the eastern study area (E2, E3). The simulation period (February 24, 2000-2007) has 29\% lower MAP (431 mm/year) from GLDAS than the long-term MAP for Jaipur (604 mm/year, 1868-2000); therefore, GLDAS precipitation estimates for the simulation period may not be representative of the long-term MAP. No station records are available for Jaipur for 2001-2007 to scale GLDAS precipitation estimates. Various scenarios were simulated to evaluate sensitivity of recharge estimates to different vegetation parameters. Simulated recharge for bare soil is $132 \mathrm{~mm} /$ year, which can be considered an upper bound on actual recharge for this time period. Crops were simulated using a maximum leaf area index of 2.0. Simulated rooting depths included $0.5,1.0,1.5$, and $2.0 \mathrm{~m}$, and corresponding recharge rates are $110,89,84$, and $70 \mathrm{~mm} /$ year. A rooting depth of $1 \mathrm{~m}$ is generally considered representative of typical crops in this region. Recharge occurs during the monsoon period. Annual recharge was spread throughout the simulation period and generally varied with annual precipitation $(r=0.79)$. Simulated recharge rates are generally consistent with CMB-based recharge estimates from rain-fed agricultural sites of $61-90 \mathrm{~mm} /$ year (E2 and E3) and from sections of profiles that represent rain-fed conditions in currently irrigated sites (E8: 50 and E5: $120 \mathrm{~mm}$ /year; Table 3).

\section{Comparisonwith recharge estimates from previous studies}

Recharge rates from the arid western sites in the Thar Desert are consistent with recharge estimates from similar regions globally, including those in the Badain Jaran desert in N. China with predominantly Asian summer monsoon precipitation (CMB recharge, $1.4 \mathrm{~mm} /$ year; $1.7 \%$ of MAP (84 mm/year; Gates et al. 2008). In contrast, there is no recharge in (semi)arid regions in perennially vegetated, semiarid regions in the southwestern USA, based on $\mathrm{Cl}$ and pressure data (Phillips 1994), or in revegetated areas of the Tengger Desert (China), based on lysimeter monitoring (1990-1995) - MAP 174 mm/year (Wang et al. 2004).

Recharge rates in the eastern study area near Jaipur were compared with those of other cultivated regions. Previous recharge studies in northwestern India in 19721973 and in 1994-1995 used injected tritium to estimate recharge rates in rain-fed grassland settings (Rangarajan and Athavale 2000). Median recharge rates were 35, 43, and $67 \mathrm{~mm} /$ year at different sites, representing 8,9 , and $14 \%$ of precipitation $(460,470$, and $491 \mathrm{~mm})$, respectively. These recharge rates are within the range of those estimated for rain-fed agriculture in the eastern study area (Table 3). Subsurface distribution of bomb tritium was used to estimate recharge in a study conducted in 1967 and 1969 at six sites in the neighboring state of Gujarat (Sukhija and Shah 1976). Three of the six sites are similar to the eastern study area, with similar or lower precipitation rates of 455, 500, and $605 \mathrm{~mm} /$ year. Recharge rates at these sites are 15, 15, and $26 \mathrm{~mm} /$ year, representing 3, 3, and $4 \%$ of precipitation, respectively, lower than the estimates from rain-fed agriculture in this study. $<$ b. Recharge rates under rain-fed cropland in the eastern study area (50-120 mm/year; $8-20 \%$ of MAP) are slightly higher than recharge rates in deep sands in northwestern Senegal (30 mm/year; 10\% of MAP of $290 \mathrm{~mm} /$ year; Gaye and Edmunds 1996) and slightly higher than recharge rates in the Southern High Plains, USA (24 mm/year, 5\% of MAP of $450 \mathrm{~mm}$ /year; Scanlon et al. 2007b), and southwestern Niger in Africa ( $25 \mathrm{~mm} /$ year; $4 \%$ of MAP of $557 \mathrm{~mm} /$ year; Favreau et al. 2009). The slightly higher recharge rates may be related to higher MAP than Senegal and to the intensity of the summer monsoon in the eastern study area and more sandy soils relative to more evenly distributed summer precipitation in the Southern High Plains 
and Niger regions and less sandy soils. It is more difficult to compare recharge rates beneath irrigated sites because of variations in irrigation application rates.

\section{Comparison with nutrient inventories from previous studies}

Nutrient availability in the Thar Desert was also compared with that of other regions. Many desert regions have high $\mathrm{NO}_{3}$ concentrations under native vegetation. Examples include regions within the southwestern USA, where peak inventories are as much as $10,000 \mathrm{~kg} \mathrm{~N} / \mathrm{ha}$ and $\mathrm{NO}_{3}$ is attributed to accumulation from atmospheric deposition during the past 10,000-15,000 years (Walvoord et al. 2003). Peak concentrations are as much as $3,100 \mathrm{mg}$ $\mathrm{NO}-\mathrm{N} / \mathrm{L}$ at $2.8 \mathrm{~m}$ depth. In contrast, some regions in the southwestern USA have very low $\mathrm{NO}_{3}$ inventories under native vegetation, e.g., 24-76 kg N/ha, Southern High Plains, USA (McMahon et al. 2006; Scanlon et al. 2008). Large $\mathrm{NO}_{3}$ reservoirs have also been found in semiarid regions in Senegal $(\leq 1,000 \mathrm{~kg} \mathrm{~N} / \mathrm{ha})$, which are attributed to $\mathrm{N}$ fixation by native trees (Deans et al. 2005). The lack of accumulation of $\mathrm{NO}_{3}$ in soils in the Thar Desert from atmospheric deposition may be attributed to downward movement of $\mathrm{NO}_{3}$ caused by recharge.

Information on $\mathrm{NO}_{3}$ levels beneath rain-fed agriculture is limited. Moderately high $\mathrm{NO}_{3}-\mathrm{N}$ inventories $(3-578 \mathrm{~kg} /$ $\mathrm{ha} / \mathrm{m}$ ) beneath rain-fed agriculture in the Southern High Plains (USA) have been attributed to mineralization and nitrification of soil organic nitrogen associated with initiation of cultivation and application of inorganic fertilizers (Scanlon et al. 2008). Inventories of $\mathrm{NO}_{3}-\mathrm{N}$ beneath irrigated agriculture are generally high $(620-1,800 \mathrm{~kg} /$ ha) throughout the USA High Plains because of higher $\mathrm{NO}_{3}$ application in irrigated sites (McMahon et al. 2006). In contrast, $\mathrm{NO}_{3}$ inventories in the eastern study area in Rajasthan beneath rain-fed agriculture and brackish irrigated agriculture are much lower (Table 1) and indicate that crop yield may be increased with additional fertilizer application.

\section{Future studies}

Work conducted in this study represents an initial reconnaissance to develop a conceptual understanding of recharge and nutrient cycling and initial estimates of recharge rates and nutrient inventories. The exercise points out a number of gaps in our knowledge that may be addressed in future studies. The CMB approach provides qualitative and quantitative information on recharge rates; however, information on $\mathrm{Cl}$ inputs is limited. Precipitation chemistry data would be valuable in reducing uncertainties in recharge rates that are based on the $\mathrm{CMB}$ approach. In addition, distinction between wet and dry fallout is important for providing data on $\mathrm{Cl}$ concentrations in bulk precipitation, which is required for the $\mathrm{CMB}$ approach. Results of this study also suggest that $\mathrm{SO}_{4}$ may be a useful indicator of recharge; therefore, data on $\mathrm{SO}_{4}$ concentrations in bulk precipitation would also be valuable. Monitoring irrigation water application rates and measuring salt concentrations in irrigation water are essential prerequisites for estimating recharge rates under irrigated sites. Recharge rates in dune/interdune settings in the western study region depend on accurate soil moisture data. The very sandy nature of the sediments may have resulted in drying during sample collection and processing. Installing soil moisture sensors would avoid some of these problems; however, installation and maintenance of monitoring stations in these remote regions are generally difficult.

Understanding nutrient availability and sources of nutrients is essential for optimal crop production. Natural accumulation of $\mathrm{NO}_{3}$ is low in these sandy soils, suggesting that $\mathrm{NO}_{3}$ levels might be limiting crop production in rain-fed agriculture in cultivated regions. Levels of $\mathrm{PO}_{4}$ are variable; however, future studies should address sources of $\mathrm{PO}_{4}$, such as precipitation and mineral dissolution. Soil organic nitrogen (SON) levels should be measured in natural and cultivated regions, and the potential for mineralization and nitrification of soil organic nitrogen should be examined. This source of $\mathrm{NO}_{3}$ is relied on solely in rain-fed agriculture in some regions of western Canada in the past and also in parts of the USA High Plains (Schimel et al. 1985; Tisdale et al. 1985). Carbon sequestration in soils through agricultural practices, i.e., minimum or no tillage and management of crop residues, could increase SON levels and may result in increased $\mathrm{NO}_{3}$ levels in soils. Assessing nutrient requirements for irrigated agriculture is essential to ensuring that crop yield is maximized and not susceptible to nutrient limitations. Quantifying $\mathrm{NO}_{3}$ levels in irrigation water and mineralization and nitrification of SON will be valuable in determining fertilizer requirements for crop production.

\section{Conclusions}

In the western study area of the Thar Desert near Jaisalmer in sparsely vegetated dune/interdune settings, estimated recharge rates are low (2.7-5.6 mm/year), 2-3\% of MAP (165 mm/year). However, these estimates may be underestimated somewhat because of potential drying of sandy soils during collection and processing. High $\mathrm{Cl}$ concentrations beneath a plantation adjacent to a canal are attributed to irrigation, and the $\mathrm{Cl}$ bulge suggests that recharge is minimal or nonexistent. Nutrient inventories in the western study area are low within $\left(\mathrm{NO}_{3}: 5-28 \mathrm{~kg}\right.$ $\mathrm{N} / \mathrm{ha}$ ) and below $\left(\mathrm{NO}_{3}: 0-14 \mathrm{~kg} \mathrm{~N} / \mathrm{ha} / \mathrm{m}\right)$ the root zone, indicating lack of $\mathrm{N}$ fixation by sparse vegetation or lack of $\mathrm{NO}_{3}$ buildup from meteoric input of $\mathrm{NO}_{3}$. Inventories of $\mathrm{PO}_{4}$ are also low.

In the eastern study area along the margin of the desert near Jaipur, soil profiles in rain-fed cultivated agriculture have low mean $\mathrm{Cl}$ concentrations ( 13 and $29 \mathrm{mg} / \mathrm{L}$ ) below the root zone ( $1 \mathrm{~m}$ depth), indicating high recharge rates of 61 and $94 \mathrm{~mm} /$ year, $10-16 \%$ of MAP $(600 \mathrm{~mm} /$ year). Areas irrigated by fresh groundwater have profiles with low mean $\mathrm{Cl}$ concentrations $(66,68$, and $86 \mathrm{mg} / \mathrm{L})$, whereas areas irrigated by saline groundwater have profiles with much higher $\mathrm{Cl}$ concentrations $(280,970$, and 
$3,900 \mathrm{mg} / \mathrm{L}$ ). The large salt accumulations in the area irrigated by brackish groundwater would require 350, 1,500, and 7,100 years to accumulate if precipitation provided the only $\mathrm{Cl}$ input. Estimating recharge rates under irrigated cropland is difficult because of uncertainties in irrigation amounts and irrigation water quality. Minimum recharge rates based on precipitation input alone are 18 , 28 , and $98 \mathrm{~mm} /$ year in the area of fresh groundwater and $0.3,5.6$, and $33 \mathrm{~mm} /$ year in the area of brackish groundwater. The two profiles with higher recharge rates $(98$ and $33 \mathrm{~mm}$ /year) reflect periods of rain-fed agriculture with associated recharge rates of 50 and $120 \mathrm{~mm} /$ year, similar to those under current rain-fed agriculture. Nutrient levels are higher in the root zone under rain-fed and irrigated cultivated sites and much lower at depth. The generally low nutrient levels beneath rain-fed agriculture and agriculture irrigated with brackish groundwater do not provide evidence of mineralization and nitrification of soil organic nitrogen. Crop production may benefit from additional fertilizer inputs, particularly in rainfed and some irrigated areas. Recharge rates near Jaipur are similar to recharge estimates from previous studies in that region, based on tritium injection. Two to five times higher recharge rates under rain-fed cropland near Jaipur relative to rain-fed cropland in many semiarid regions (Southern High Plains, USA; SW Niger) may be attributed to higher MAP than Senegal and to the very sandy nature of the soils and intensity of summer monsoon precipitation in the Jaipur region. Recharge rates of 50-120 mm/ year under rain-fed agriculture indicate that irrigation of $\sim 20-40 \%$ of cultivated land with $300 \mathrm{~mm} /$ year should be sustainable from a water-quantity perspective.

Results from this study suggest that the CMB approach provides reliable recharge rates for rain-fed agriculture and bounding estimates for irrigated agriculture in the eastern study area. Similar recharge rates based on $\mathrm{SO}_{4}$ increase confidence in these recharge estimates. Modeling analyses based on available climatic forcing data and estimates of soil hydraulic properties suggest that recharge estimates based on the tracer data are reasonable.

\section{Acknowledgments}

We would like to acknowledge the Jackson School of Geosciences for financial support for conducting this study. We would also like to thank Prof. A. L. Ramanathan (Jawharlal Nehru University, India) for guidance in field selection, Mr. P. Kumar (Jawharlal Nehru University) for assisting with fieldwork in 2007, Prof. F. Perez (Dept. of Geography and the Environment, Univ. of Texas at Austin, USA) for sample shipment, S. Davidson (MSc. student, Jackson School of Geosciences, USA) for laboratory work, L. Longuevergne for obtaining GLDAS forcing data (Bureau of Economic Geology, USA), and local residents for access to drilling sites. Publication authorized by the Director, Bureau of Economic Geology.

\section{References}

Allison GB, Hughes MW (1983) The use of natural tracers as indicators of soil-water movement in a temperate semi-arid region. J Hydrol 60: 157-173.

Asner GP, Archer S, Hughes RF, Ansley RJ, Wessman CA (2003) Net changes in regional woody vegetation cover and carbon storage in Texas drylands, 1937-1999. Glob Chang Biol 9:316-335.
Bredehoeft JD (2002) The water budget myth revisited: why hydrogeologists model. Ground Water 40: 340-345.

Carsel RF, Parrish RS (1988) Developing joint probability distributions of soil water retention characteristics. Water Resour Res 24: 755-769.

Christensen JH, Hewitson B, Busuioc A, Chen A, Gao X, Held I, Jones R, Kolli RK, Kwon W-T, Laprise R, Magaña Rueda V, Mearns L, Menéndez CG, Räisänen J, Rinke A, Sarr A, Whetton P (2007) Regional climate projections. In: Solomon S, Qin D, Manning M, Chen Z, Marquis M, Averyt KB, Tignor M, Miller HL (eds.) The Physical Science Basis Contribution of Working Group I to the Fourth Assessment Report of the Intergovernmental Panel on Climate Change. Cambridge University Press, Cambridge and New York.

Cook PG, Herczeg A (2000) Environmental Tracers in Subsurface Hydrology. Kluwer, Dordrecht, The Netherlands, 529 p.

Deans JD, Edmunds WM, Lindley DK, Gaye CB, Dreyfus B, Nizinski JJ, Neyra M, Ingleby K, Munro RC (2005) Nitrogen in interstitial waters in the Sahel: natural baseline, pollutant or resource? Plant Soil 271: 47-62.

Deb Roy A, Shah T (2003) Socio-ecology of groundwater irrigation in India. In: Llamas R, Custodio E (eds.) Intensive Use of Groundwater: Challenges and Opportunities. Swets and Zetlinger, Lisse, The Netherlands, 307-336.

Devlin JF, Sophocleous M (2005) The persistence of the water budget myth and its relationship to sustainability. Hydrogeol J13: 549554. doi:10.1007/s10040-004-0354-0.

FAO (2008) Aquastat. FAO, Rome. http://www.fao.org/nr/water/ aquastat/main/index.stm. Cited June 2008.

Favreau G, Cappelaere B, Massuel S, Leblanc M, Boucher M, Boulain N, Leduc C (2009) Land clearing, climate variability, and water resources increase in semiarid southwest Niger: a review. Water Resour Res 45. doi:W00a16 10.1029/2007wr006785.

Fayer MJ, Gee GW, Rockhold ML, Freshley MD, Walters TB (1996) Estimating recharge rates for a groundwater model using a GIS. J Environ Qual 25: 510-518.

Feddes RA, Kowalik PJ, Zaradny H (1978) Simulation of field water use and crop yield. Simulation Monographs. PUDOC, Wageningen, The Netherlands, $189 \mathrm{p}$.

Fischer G, Shah M, van Velthuizen H (2002) Climate change and agricultural vulnerability. Intl Inst Appl Syst Anal:Contribution to World Summit on Sustainable Development, Johannesburg, South Africa, August 26 to September 4, 2002, 151 p.

Gates JB, Edmunds WM, Ma J, Sheppard PR (2008) A 700-year history of groundwater recharge in the drylands of NW China. Holocene 18(7): 1,045-1,054.

Gaye CB, Edmunds WM (1996) Groundwater recharge estimation using chloride, stable isotopes and tritium profiles in the sands of northwestern Senegal. Environ Geol 27: 246-251.

Gupta SK, Deshpande RD (2004) Water for India in 2050: first-order assessment of available options. Curr Sci 86: 1,216-1,224.

Jain SK, Agarwal PK, Singh VP (2007) Hydrology and Water Resources of India. Springer, Amsterdam, $1258 \mathrm{p}$.

Keese KE, Scanlon BR, Reedy RC (2005) Assessing controls on diffuse groundwater recharge using unsaturated flow modeling. Water Resour Res 41, W06010. doi:06010.01029/02004WR003841.

Kumar R, Singh RD, Sharma KD (2005) Water resources of India. Curr Sci 89: 794-811.

McMahon PB, Dennehy KF, Bruce BW, Bohlke JK, Michel RL, Gurdak JJ, Hurlbut DB (2006) Storage and transit time of chemicals in thick unsaturated zones under rangeland and irrigated cropland, High Plains, United States. Water Resour Res 42, W034013.

Mukhopadhyay B, Datar SV, Srivastava HN (1992) Precipitation chemistry over the India region. Mausam 43: 249-258.

Phillips FM (1994) Environmental tracers for water movement in desert soils of the American Southwest. Soil Sci Soc Am J 58:1424.

Pockman WT, Sperry JS (2000) Vulnerability to xylem cavitation and the distribution of Sonoran desert vegetation. Am J Bot 87: 1,2871,299 . 
Postel SL (1997) Last Oasis: Facing Water Scarcity, 2nd ed. Norton, New York.

Rangarajan R, Athavale RN (2000) Annual replenishable ground water potential of India: an estimate based on injected tritium studies. J Hydrol 234: 38-53.

Rockstrom J, deRouw A (1997) Water, nutrients and slope position in on-farm pearl millet cultivation in the Sahel. Plant Soil 195: 311327.

Rodell M, Houser PR, Jambor U, Gottschalck J, Mitchell K, Meng CJ, Arsenault K, Cosgrove B, Radakovich J, Bosilovich M, Entin JK, Walker JP, Lohmann D, Toll D (2004) The global land data assimilation system. Bull Am Meteor Soc 85: 381-394.

Sahai B, Rajawat AS, Bahuguna IM, Arya AS, Sharma AK, Sharma DC, Porwal CP, Chakravarty SK, Rathore DS (1993) Hydrogeomorphological mapping of Jaisalmer and Bikaner districts (Rajasthan) at 1:1-50,000 scale using satellite data. J Arid Environ 25: 163-172.

Scanlon BR, Healy RW, Cook PG (2002) Choosing appropriate techniques for quantifying groundwater recharge. Hydrogeol J 10: 18-39.

Scanlon BR, Keese K, Reedy RC, Simunek J, Andraski BJ (2003) Variations in flow and transport in thick desert vadose zones in response to paleoclimatic forcing (0-90 kyr): field measurements, modeling, and uncertainties. Water Resour Res 39, W01179.

Scanlon BR, Reedy RC, Stonestrom DA, Prudic DE, Dennehy KF (2005) Impact of land use and land cover change on groundwater recharge and quality in the southwestern USA. Glob Chang Biol 11: 1,577-1,593.

Scanlon BR, Reedy RC, Tachovsky JA (2007a) Semiarid unsaturated zone chloride profiles: archives of past land use change impacts on water resources in the southern High Plains, United States. Water Resour Res 43, W06423.

Scanlon BR, Jolly I, Sophocleous M, Zhang L (2007b) Global impacts of conversions from natural to agricultural ecosystems on water resources: quantity versus quality. Water Resour Res 43, W03437.

Scanlon BR, Reedy RC, Bronson KF (2008) Impacts of land use change on nitrogen cycling archived in semiarid unsaturated zone nitrate profiles, southern High Plains, Texas. Environ Sci Technol 42: 7,566-7,572. DOI: 10.1021/es800792w.

Scanlon BR, Stonestrom DA, Reedy RC, Leaney FW, Gates J, Cresswell RG (2009) Inventories and mobilization of unsaturated zone sulfate, fluoride, and chloride related to land use change in semiarid regions, southwestern United States and Australia. Water Resour Res 45, W00A18. DOI: 10.1029/2008wr006963.

Schimel D, Stillwell MA, Woodmansee RG (1985) Biogeochemistry of $\mathrm{C}, \mathrm{N}$, and $\mathrm{P}$ in a soil Catena of the Shortgrass Steppe. Ecology 66: 276-282.

Sharma D (1966) Rajasthan through the Ages: A Comprehensive and Authentic History of Rajasthan, vol. 1. Rajasthan State Archives, Government of Rajasthan, Rajasthan, India.

Shiklomanov IA (2000) Appraisal and assessment of world water resources. Water Int 25: 11-32.

Siebert S, Doll P, Hoogeveen J, Faures JM, Frenken K, Feick S (2005) Development and validation of the global map of irrigation areas. Hydrol Earth Syst Sci 9: 535-547.

Simunek J, Van Genuchten MT, Sejna M (2005) The hydrus-1D software package for simulating the one-dimensional movement of water, heat, and multiple solutes in variably-saturated media, version 3.0, HYDRUS Software Series 1, Department of Environmental Sciences, University of California, Riverside, CA, $270 \mathrm{p}$.

SRSA (1999) Ground Water Atlas of Rajasthan. State Remote Sensing Application Centre, Department of Science and Technology, Government of Rajasthan, Rajasthan, India, 370 p.

Sukhija BS, Shah CR (1976) Conformity of groundwater recharge rate by tritium method and mathematical modelling. J Hydrol 30:167-178.

UN-DESA-PD (2002) World Population Prospects: 2002. United Nations Department of Economic and Social Affairs-Population Division, UN, New York.
UNEP (1991) Status of desertification and implementation of the United Nations Plan of Action to Combat Desertification. Report of the Executive Director to the Governing Council, Third Special Session, UNEP, Nairobi, Kenya.

Tisdale SL, Nelson WL, Beaton JD (1985) Soil Fertility and Fertilizers, 4th ed. Macmillan, New York.

Vose RS, Peterson TC, Hulme M (1998) The global historical climatology network precipitation database. Proc of the Ninth Symposium on Global Change Studies, January 1998, Phoenix, AZ.

Walvoord MA, Phillips FM, Stonestrom DA, Evans EC, Hartsough PC, Newman BD, Striegl RG (2003) A reservoir of nitrate beneath desert soils. Science 302: 5,647.

Wang XP, Brown-Mitic CM, Kang ES, Zhang JG, Li XR (2004) Evapotranspiration of Caragana korshinskii communities in a revegetated desert area: Tengger Desert, China. Hydrol Process 18: 3,2933,303

Wasson RJ, Rajaguru SN, Misra VN, Agrawal DP, Dhir RP, Singhvi AK, Kameswara Rao K (1983) Geomorphology, late Quaternary stratigraphy and palaeoclimatology of the Thar dune field. Zeitschr Geomorphog (Supplementband) 45:117-151

White MA, Asner GP, Nemani RR, Privette JL, Running SW (2000) Measuring fractional cover and leaf area index in arid ecosystems: digital camera, radiation transmittance, and laser altimetry methods. Remote Sens Environ 74: 45-57.

Zeng XB (2001) Global vegetation root distribution for land modeling. J Hydrometeorol 2: 525-530. 